\title{
E-Learning in COVID-19 Pandemic: Preparedness, Expectations, and Concerns of Private School Students
}

\author{
Nilda W. Balsicas ${ }^{1, *}$, Elgien C. Padohinog ${ }^{1}$, Pauline Arvian R. Hala ${ }^{2}$, Freddie B. Bulauan ${ }^{3}$ \\ ${ }^{1}$ Research Development Office, St. Dominic College of Asia, 4102 Bacoor, Cavite, Philippines \\ ${ }^{2}$ ICT Department, St. Dominic College of Asia, 4102 Bacoor, Cavite, Philippines \\ ${ }^{3}$ Administrative Department, Region V, Commission on Higher Education (CHED), Philippines
}

Received December 13, 2020; Revised February 18, 2021; Accepted March 12, 2021

\section{Cite This Paper in the following Citation Styles}

(a): [1] Nilda W. Balsicas, Elgien C. Padohinog, Pauline Arvian R. Hala, Freddie B. Bulauan, "E-Learning in COVID-19 Pandemic: Preparedness, Expectations, and Concerns of Private School Students," Universal Journal of Educational Research, Vol. 9, No. 3, pp. 675 - 682, 2021. DOI: 10.13189/ujer.2021.090327.

(b): Nilda W. Balsicas, Elgien C. Padohinog, Pauline Arvian R. Hala, Freddie B. Bulauan (2021). E-Learning in COVID-19 Pandemic: Preparedness, Expectations, and Concerns of Private School Students. Universal Journal of Educational Research, 9(3), 675 - 682. DOI: 10.13189/ujer.2021.090327.

Copyright $\odot 2021$ by authors, all rights reserved. Authors agree that this article remains permanently open access under the terms of the Creative Commons Attribution License 4.0 International License

\begin{abstract}
The E-learning has become the trend since the surge of COVID-19 pandemic. Higher education institutions were compelled to continuously deliver instruction despite the pandemic. The study aimed to assess the students' perceptions towards online learning relative to the availability of online devices, preparedness, expectations, and concerns along with the activities considered, prior experiences, skills acquisition, and competency development. The study utilized the exploratory descriptive survey research design. One thousand, one hundred and thirty-eight $(1,138)$ college students participated in this study who were enrolled in the Second Semester of the School Year 2019-2020. The results indicated that students became aware of online tools as they acquired varied experiences in online classes such as slow internet connection, expenses in data load, or the monthly expenditures of internet connectivity regardless of the provider. It was further revealed that students preferred more in expressing their questions during online classes and in attending to self-paced activities. Students were also unsure if they have already developed the expected skills and competencies in e-learning. Based on the findings, it is recommended that higher education institutions should be ready in thinking creative alternative modes and in bringing new perspectives that will help and guide the students in their learning. Moreover, teachers or curriculum developers are encouraged to redesign curriculum plan, activities, and assessment tasks to enhance attainment of learning outcome in e- learning
\end{abstract}

delivery of instruction.

Keywords E-Learning, COVID-19, Preparedness, Expectations, Concerns

\section{Introduction}

The Coronavirus disease (COVID-19) pandemic has brought the global economy downward. Schools and colleges all over the world were forced to shut down due to continuous increase in cases. Miks and Mcllwaine [14], stated that majority of the countries have announced indefinite closure of schools, which impacted around 1.6 billion children and young people (or more than 91 percent of learners worldwide). The education systems were disrupted and impacting on the students' learning, as leaders are struggling to continue the teaching-learning process in the classroom environment during the remaining days of the semester and in the next succeeding academic years.

In compliance with the health and safety protocols, the Commission on Higher Education (CHED) released advisories that promote prevention, control, and mitigation of the said virus in all Higher Education Institutions (HEIs) in the Philippines. Based on the CHED COVID Advisory No. 7 dated May 24, 2020, in-person classes including on-the-job and internship programs were suspended until 
further instruction from the Inter-Agency Task Force (IATF) or issuance by the proper government authority that quarantine in the area should be lifted. Mass gatherings like in-person graduation ceremonies and other school-related activities were also prohibited in compliance with the minimum health standards. Furthermore, all HEIs which are using the old academic calendar (June-May) were recommended to change the academic year that would start in August 2020 or beyond. As provided in CHED Advisory No. 6 dated April 13, 2020, HEIs that have a new academic calendar were authorized to extend their semester for one month in completing the academic requirements and responsibilities.

In terms of students' welfare, HEIs were advised to set up a clear communication plan for their students and personnel ensuring that critical and significant concerns are addressed. Institutions are encouraged to communicate and transact using non-face-to-face strategies like online and social media platforms, phone, e-mail, and/or courier services, among others. But they should respect the decision of families not to send their children to school due to safety and health concerns surrounding the health crisis. At the same time, HEIs should also coordinate with Local Government Units (LGUs) to assist and keep in touch with their students where there is no public transportation yet in a particular area and to help in bringing educational materials and information to the best of their needs and interests. All colleges and universities should notify their students and personnel on the enrolment process and specific education delivery mode that will be achieved for the Academic Year 2020-2021, as well as facilitate foreign students who wish to return to their home countries and agree to adopt alternative modes of learning to complete their academic requirements for the current semester and in the succeeding academic year [9].

With this current global crisis, most educational institutions including the Philippines have resorted to e-learning or online learning. E-learning involves the information and communication tools for online teaching and learning resources. E-learning includes content and instruction relevant to the learning objectives, while it helps and motivates students to build new knowledge and skills based on their individual learning goals [7] [10]. Salamat et al., [19] added that e-learning allows time flexibility for the students' acquisition of knowledge and skills and gives them access to global world for study purposes. Thus, this method of learning makes an alternative to traditional face-to-face courses. Ali [2] stated that during COVID-19 pandemic, this widespread gives us the opportunity to embrace online learning as an instructional framework that would keep abreast with the fast rise of new technologies, in such a way making online, blended, and distance learning a need in higher education institutions all over the world.

However, challenges arise in moving from a physical classroom to an emergency remote teaching environment [21]. Adopting online environment requires ample preparation. Since online learning is new to students, they were not hesitant and not fully prepared in addition to technological and financial hindrances [1]. Cigdem \& Ozturk [6], explained that online learning technologies such as videos, podcasts, and online quizzes aim to prepare students for their academic purposes that cater them to their different learning styles to try different tools and choose which ones fit their needs best.

While there have been studies related to distance learning, this is the first at the College. Distance learning or e-learning opened opportunities for individuals (who could not go to school physically for certain reasons) to reach a certain goal in meeting their educational needs and interests; thus, beneficial for them in enhancing their performances [12] [16]. Reyes-Chua et al., [18] emphasized that both professors and students could adjust to these new changes in acquiring the 21 st century skills of learning with this method. In contrast, Rasouli et al., [17] cited reasons such as lack or inadequacy of information technology courses, lack of electronic courses in different schools, little facilities, and computers for Internet usage, and lack of academic staff knowledge and skills in the e-learning which resulted in the low level of students' skills on computer and the Internet. Students could not pay attention to the lesson; thus, this teaching-learning process becomes ineffective because of the challenges that students encountered [20]. However, those problems mentioned are yet to be enacted to drive the learners to better achievement and self-esteem.

E-learning is now essential for students to continue their education in building knowledge and skills. Students have their own perceptions of online learning during COVID-19 pandemic since the shift to e-learning is new and immediate for them. Therefore, professors should encourage students to participate in the online learning by engaging them in a variety of activities and tools necessary for the online class. It is important that this new trend will serve students to become more efficient in utilizing those tools and in exploring the diverse concepts through this kind of learning. As online education becomes a trend for borderless education, it is essential that the academic community needs to adapt new and creative ways of providing knowledge and skills in support of the institution.

The objective of this study is to assess the students' perceptions towards online learning relative to the availability of online devices, preparedness, expectations, and concerns. The results are premised to shed light on curriculum planning, implementation and assessment during the COVID-19 pandemic.

\section{Methods}

The study utilized exploratory descriptive survey research design. Creswell and Creswell [8], said that a survey research describes trends, attitudes, or opinions of a 
population by studying a sample of that population. One thousand, one hundred and thirty-eight $(1,138)$ college students, who were enrolled in the Second Semester of the School Year 2019-2020, participated in this study with the use of simple random sampling method to ensure that each of them will have even chance of being selected. These participants came from the four areas: School of Arts, Sciences and Education (158), School of Business and Computer Studies (351), School of Health Sciences Profession (413), and School of International Hospitality and Tourism Management (216).

An online survey form was developed by the researchers using the feedback of students on online teaching and learning. Feedback included the readiness of the College to offer online classes, preparedness of students to participate in the online activities, and accessibility to internet, among others. These concepts were transformed into Yes-No statements. In addition to, information technology experts and Education faculty members were asked to validate the contents of the instruments. Some items were improved from Yes-No statements to Likert-scale formats.

Response options to the multiple-choice questions were based on the concerns related to online development program and virtual education tools, including a 5-point Likert scale in assessing the development of student skills and competencies. The link for the survey was emailed to students by the administrators through an online Google form.

Survey results were recorded using Google Forms and a Microsoft Excel spreadsheet was used to collect students' responses. Data were collected and analyzed using descriptive statistics in forms of frequency and percentage distribution and weighted mean to determine if online learning is good for students. Results are shown in tables with percentages of responses displayed.

\section{Results and Discussion}

\subsection{Availability of Devices and Platforms during Online Learning}

Table 1 shows the students' availability of online devices during online learning. The available online devices used by students during E-learning and the delivery of the lessons reveal that out of 1,138 respondents, 350 $(30.76 \%)$ students used smartphones as their most available resource at home; laptop (27.68\%); Wi-Fi hotspot using mobile data (4.48\%); desktop (3.60\%); tablet $(0.44 \%)$; and non-smartphone $(0.18 \%)$; while, almost one-third of the students (32.86\%) did not give answers.

This result further shows that most students used smartphones which were the most available gadget during that period, while laptop usage was next. In a study by Briz-Ponce et al., [5] these technologies could help improve the quality of the learning process through the students. They enable learners to benefit from their potential pedagogical and educational uses, and also promote and encourage the use of these tools as creative teaching and learning methods, which include smartphones.

Table 1. List of devices used during online learning $(\mathrm{n}=1,138)$

\begin{tabular}{ccc}
\hline Devices & n & $\%$ \\
\hline Smartphone & 350 & $30.76 \%$ \\
Laptop & 315 & $27.68 \%$ \\
Wi-Fi hotspot using mobile data & 51 & $4.48 \%$ \\
Desktop & 41 & $3.60 \%$ \\
Tablet & 5 & $0.44 \%$ \\
Non-smartphone & 2 & $0.18 \%$ \\
Others (no answers) & 374 & $32.86 \%$ \\
\hline
\end{tabular}

In Table 2, only 55 students preferred Facebook Messenger (4.83\%) for online class; followed by videos such as pre-recorded (3.51\%); Google Classroom (2.90\%); Google Meet and Hangouts (2.72\%); and Edmodo (1.58\%). It is reported that 915 student responses $(80.40 \%)$ were not mentioned in suggesting their respective virtual tools for their online learning. This means that majority of students remained "unsure" of what virtual platforms they would prefer to use to enhance their learning and feedback.

Virtual platforms are part in keeping students motivated and engaged with the lessons in their E-learning classes. Moreillon [16] said that these tools can be useful to enhance learning and support teachings are developed daily. These allow students to conveniently learn anything without limitations and help them to facilitate communication and collaboration among people. At any time, learners can have access to content and materials because all the information to different platforms is organized and updated.

Table 2. Virtual platforms of students for delivery of online lessons (n $=1,138$ )

\begin{tabular}{ccc}
\hline Virtual platforms & $\mathbf{N}$ & $\%$ \\
\hline Facebook Messenger & 55 & $4.83 \%$ \\
Videos & 40 & $3.51 \%$ \\
Google Classroom & 33 & $2.90 \%$ \\
Google Meet/Hangouts & 31 & $2.72 \%$ \\
Edmodo & 18 & $1.58 \%$ \\
Others & 915 & $80.40 \%$ \\
\hline
\end{tabular}

\subsection{Experiences and Activities of Students during Online Classes}

In this study, experiences included the buying of load for internet, internet connection speed, bandwidth use, and length of time spend for online classes. As illustrated in Table 3, the students' experiences to access the internet as represented by $52.46 \%$ of the students used to buy load or data when accessing to internet connection. With that, $80.84 \%$ of the students reported to have slow internet 
connection which affected their online connectivity. These experiences of the students were clear indicators of the disruptive effect of COVID-19 which shows the status of connectivity of the internet during the disruptive period of the academic year.

It is further revealed that, $497(43.68 \%)$ of the students consumed more than $500 \mathrm{MB}$ from their internet megabyte (MB) data use. Meanwhile, the length of time used in a lesson or activity was based on the number of units a subject is accorded to, usually 3 -unit/3 hours in a curriculum. However, $65.20 \%$ answered that more than 30 minutes were utilized when learning using different online discussions. This means that most students spend longer times in their E-learning classes. These experiences could provide new insights and online strategies for developers of online curriculum. It is suggested that teachers should review and evaluate student experiences during online for better results of students' learning outcomes.

Table 3. Experiences of students during online classes $(n=1,138)$

\begin{tabular}{|c|c|c|c|}
\hline Experiences & Options & $\mathbf{n}$ & $\%$ \\
\hline \multirow{2}{*}{$\begin{array}{l}\text { Buying of load for } \\
\text { internet }\end{array}$} & Yes & 597 & $52.46 \%$ \\
\hline & No & 541 & $47.54 \%$ \\
\hline \multirow{3}{*}{$\begin{array}{l}\text { Internet connection } \\
\text { speed }\end{array}$} & Very fast & 5 & $0.44 \%$ \\
\hline & Fast & 213 & $18.72 \%$ \\
\hline & Slow & 920 & $80.84 \%$ \\
\hline \multirow{3}{*}{ Bandwidth use } & $300 \mathrm{MB} /$ week & 408 & $35.85 \%$ \\
\hline & $500 \mathrm{MB} /$ week & 233 & $20.47 \%$ \\
\hline & $\begin{array}{c}\text { More than } 500 \\
\mathrm{MB} / \text { week }\end{array}$ & 497 & $43.68 \%$ \\
\hline \multirow{4}{*}{$\begin{array}{c}\text { Length of time spent } \\
\text { in an online class per } \\
\text { subject }\end{array}$} & 10 minutes & 75 & $6.59 \%$ \\
\hline & 20 minutes & 119 & $10.46 \%$ \\
\hline & 30 minutes & 202 & $17.75 \%$ \\
\hline & More than 30 minutes & 742 & $65.20 \%$ \\
\hline
\end{tabular}

In Table 4, the activities of students during online classes include, reading the articles according to their own pace or time is the least preferred activity among students with a mean of 2.56 and a standard deviation of 1.27. This is followed by watching a pre-recorded lecture $(\mathrm{M}=2.72, \mathrm{SD}$ $=1.29$ ); scheduled meeting with teachers for question or content clarification $(\mathrm{M}=2.77, \mathrm{SD}=1.16)$; scheduled meeting with teachers and classmates for brief discussion $(\mathrm{M}=2.81, \mathrm{SD}=1.19)$; reading a teacher's blog about our topic ( $\mathrm{M}=2.86, \mathrm{SD}=1.19)$; expressing his or her question in a chat room $(\mathrm{M}=2.86, \mathrm{SD}=1.21)$; reading PowerPoint presentations $(\mathrm{M}=2.86, \mathrm{SD}=1.22)$; and while expressing his or her question in a discussion board $(\mathrm{M}=2.93, \mathrm{SD}=$ $1.19)$ is the most preferred activity in the online class.

This indicates that despite remote or online activities students still preferred to express their opinions or interact with classmates or teachers. Engagement with their classmates or teachers such as expressing questions in a discussion board are important to deliver a feedback to increase the sense of progress so that no one would be left behind in a virtual setting. This supports the study of Martin \& Bolliger [13], wherein engagement strategies that facilitate interactions with instructors were valued more than strategies that focus on the learning materials within students. Online learners want instructors who support, listen to, and connect with them because they know that students would pay attention to the professors, much as they would respond to that situation.

Table 4. Activities of students during online classes $(\mathrm{N}=1,138)$

\begin{tabular}{|c|c|c|c|}
\hline No. & Statements & Mean & SD \\
\hline 1 & $\begin{array}{l}\text { Reading the articles according to } \\
\text { my own pace/time }\end{array}$ & 2.56 & 1.27 \\
\hline 2 & Watching a pre-recorded lecture & 2.72 & 1.29 \\
\hline 3 & $\begin{array}{l}\text { Scheduled meeting with teachers } \\
\text { for question or content clarification }\end{array}$ & 2.77 & 1.16 \\
\hline 4 & $\begin{array}{l}\text { Scheduled meeting with teachers } \\
\text { and classmates for brief discussion }\end{array}$ & 2.81 & 1.19 \\
\hline 5 & $\begin{array}{c}\text { Reading a teacher's blog about our } \\
\text { topic }\end{array}$ & 2.86 & 1.19 \\
\hline 6 & $\begin{array}{c}\text { Expressing my question in chat } \\
\text { room }\end{array}$ & 2.86 & 1.21 \\
\hline 7 & Reading PowerPoint presentations & 2.86 & 1.22 \\
\hline 8 & $\begin{array}{l}\text { Expressing my question in } \\
\text { discussion board }\end{array}$ & 2.93 & 1.19 \\
\hline
\end{tabular}

\subsection{Expectations of Students in Online Classes}

Students' expectations were revealed in Table 5. The table shows that $219(19.24 \%)$ of the students' activities were self-paced. It is followed by $90(7.91 \%)$ of the participants who expressed that they could complete a project as scheduled; 68 (5.98\%) who could participate in all class discussions; $64(5.62 \%)$ who could listen to an online lecture; $52(4.57 \%)$ who answered that there is an immediate feedback on assessed activities or major exams; $42(3.69 \%)$ who could collaborate with their classmates; and $41(3.61 \%)$ who could discuss with their classmates. Others did not provide answer. This could mean that students remain unsure of their expectations from online classes.

Since activities are self-paced, said statement was rated the highest; it showed that students expected teachers to provide enough time space for students to complete their activities or assigned tasks. In short, teachers may create a map of schedule and task analysis for each group of learners. In this way, students would be able to perform and build more confidence in meeting online learning requirements. Alqurashi [3], mentioned that through enhancing students' performance achievement helps the learners build a clear sense of self-efficacy based on their prior successful experiences. Students strengthen their confidence by successfully accomplishing tasks such as dealing with completing online activities, managing course schedule.

Moreover, expectations from students' behavior during E-learning/ online classes vary from time to time. However, with the normal classroom instruction transitioning to 
e-learning, it is important that the institution creates clear and established goals and objectives anticipated to maximize the success of the learners. Umbit \& Taat [22], reiterated that expectations of e-learning can provide a positive effect and increase the levels of satisfaction among students as well as enhance overall learning performance. Thus, students are willing to adopt different changes in the teaching-learning process in ensuring positive and productive learning environment, as well as being proactive with their management skills toward professors.

Table 5. Expectations of students in online classes $(n=1138)$

\begin{tabular}{ccc}
\hline Statements & $\mathbf{n}$ & $\boldsymbol{\%}$ \\
\hline Activities are self-paced. & 219 & $19.24 \%$ \\
I can complete a project as scheduled. & 90 & $7.91 \%$ \\
I can participate in all class discussions. & 68 & $5.98 \%$ \\
I can listen to an online lecture. & 64 & $5.62 \%$ \\
There is immediate feedback on assessed & 52 & $4.57 \%$ \\
activities or major exams. & 42 & $3.69 \%$ \\
I can collaborate with my classmates. & 41 & $3.61 \%$ \\
I can discuss with my classmates. & 562 & $49.38 \%$ \\
\hline
\end{tabular}

\subsection{Perception of Students on the Desired Skills Acquisition and Competency Development}

The perceptions in the development of desired skills and competencies show that students $(38.22 \%)$ are not sure whether their research skill has improved. It is also said that majority of the students (39.28\%) are not sure whether their writing skill has improved; whereas students (39.28\%) are not sure if their ability to think critically and solve problems had improved. It is reported that students (37.61\%) agreed in their improvement in using search engines and software tools; however, students $(39.02 \%)$ are not sure that their moral and spiritual advocacy is better than before.

Moreover, $37.08 \%$ of the students agree that they become more conscious in community and collaborative engagement; students $(37.52 \%)$ are not sure that their ability to understand the content of their topics is better than before. It is also mentioned that $40.60 \%$ of the students agree that they become more independent in working in their academic task; while $34.97 \%$ are not sure that they become more creative and innovative than before. In addition, majority of the students (40.42\%) are not sure that their perspectives in cultural advocacy become wider. Among the perceptions on desired skill, students rated agree to the acquisition of skill in Community and Collaborative Engagement and to Self-directed Learning. The students rated unsure to the rest of the desired skills. It means that the participants have mixed perceptions whether the desired skills were acquired and competencies were developed during online learning.

However, Landrum [11] emphasized that a student needs to boost his or her confidence that one can learn through online classes as a useful skill. It signifies that an individual will learn anything if one is ready to make a positive change in his or her self-development in the virtual environment. The results suggest that teachers or facilitators should exert commitment to be more creative and innovative in moving forward the learning management system to meet the targets of E-learning and the development of the expected students' acquired attribute. 
Table 6. Perceptions on development of skills and competencies of students

\begin{tabular}{|c|c|c|c|c|c|c|c|c|c|c|c|c|c|}
\hline \multirow{2}{*}{ No. } & \multirow{2}{*}{ Statements } & \multicolumn{2}{|c|}{$\begin{array}{c}\begin{array}{c}\text { Strongly } \\
\text { agree }\end{array} \\
\end{array}$} & \multicolumn{2}{|c|}{ Agree } & \multicolumn{2}{|c|}{ Not sure } & \multicolumn{2}{|c|}{ Disagree } & \multicolumn{2}{|c|}{$\begin{array}{l}\text { Strongly } \\
\text { disagree }\end{array}$} & \multicolumn{2}{|c|}{ Others } \\
\hline & & $\mathbf{n}$ & $\%$ & $\mathbf{n}$ & $\%$ & $\mathbf{n}$ & $\%$ & $\mathbf{N}$ & $\%$ & $\mathbf{n}$ & $\%$ & $\mathbf{n}$ & $\%$ \\
\hline 1 & $\begin{array}{l}\text { I believe my } \\
\text { research skill has } \\
\text { improved. }\end{array}$ & 53 & $4.66 \%$ & 335 & $29.44 \%$ & 435 & $38.22 \%$ & 161 & $14.15 \%$ & 135 & $11.86 \%$ & 19 & $1.67 \%$ \\
\hline 2 & $\begin{array}{c}\text { My writing skill has } \\
\text { improved. }\end{array}$ & 50 & $4.39 \%$ & 313 & $27.50 \%$ & 447 & $39.28 \%$ & 179 & $15.73 \%$ & 126 & $11.07 \%$ & 23 & $2.02 \%$ \\
\hline 3 & $\begin{array}{l}\text { My ability to think } \\
\text { critically and solve } \\
\text { problem has } \\
\text { improved. }\end{array}$ & 52 & $4.57 \%$ & 327 & $28.73 \%$ & 447 & $39.28 \%$ & 167 & $14.67 \%$ & 124 & $10.90 \%$ & 21 & $1.85 \%$ \\
\hline 4 & $\begin{array}{l}\text { My ability to use } \\
\text { search engines and } \\
\text { software tools has } \\
\text { improved. }\end{array}$ & 110 & $9.67 \%$ & 428 & $37.61 \%$ & 362 & $31.81 \%$ & 120 & $10.54 \%$ & 93 & $8.17 \%$ & 25 & $2.20 \%$ \\
\hline 5 & $\begin{array}{l}\text { My moral and } \\
\text { spiritual advocacy is } \\
\text { better than before. }\end{array}$ & 74 & $6.50 \%$ & 339 & $29.79 \%$ & 444 & $39.02 \%$ & 150 & $13.18 \%$ & 118 & $10.37 \%$ & 13 & $1.14 \%$ \\
\hline 6 & $\begin{array}{l}\text { I become more } \\
\text { conscious in } \\
\text { community and } \\
\text { collaborative } \\
\text { engagement. }\end{array}$ & 94 & $8.26 \%$ & 422 & $37.08 \%$ & 387 & $34.01 \%$ & 124 & $10.90 \%$ & 96 & $8.44 \%$ & 15 & $1.32 \%$ \\
\hline 7 & $\begin{array}{l}\text { My ability to } \\
\text { understand the } \\
\text { content of our topics } \\
\text { is better than before. }\end{array}$ & 37 & $3.25 \%$ & 278 & $24.43 \%$ & 427 & $37.52 \%$ & 201 & $17.66 \%$ & 180 & $15.82 \%$ & 30 & $2.64 \%$ \\
\hline 8 & $\begin{array}{l}\text { I become more } \\
\text { independent in } \\
\text { working in my } \\
\text { academic task. }\end{array}$ & 120 & $10.54 \%$ & 462 & $40.60 \%$ & 313 & $27.50 \%$ & 114 & $10.02 \%$ & 104 & $9.14 \%$ & 25 & $2.20 \%$ \\
\hline 9 & $\begin{array}{c}\text { I become more } \\
\text { creative and } \\
\text { innovative than } \\
\text { before. }\end{array}$ & 67 & $5.89 \%$ & 351 & $30.84 \%$ & 398 & $34.97 \%$ & 180 & $15.82 \%$ & 129 & $11.34 \%$ & 13 & $1.14 \%$ \\
\hline 10 & $\begin{array}{l}\text { My perspectives in } \\
\text { cultural advocacy } \\
\text { become wider. }\end{array}$ & 71 & $6.24 \%$ & 325 & $28.56 \%$ & 460 & $40.42 \%$ & 140 & $12.30 \%$ & 122 & $10.72 \%$ & 20 & $1.76 \%$ \\
\hline
\end{tabular}

\subsection{Concerns about Online Learning}

In Table 7, five hundred thirty-eight (538) or $47.28 \%$ of the students have their concerns when attending online classes. While more than one-third (34.18\%) of the students do not have any concerns to share. Almost one-fifth $(18.54 \%)$ of the students did not know what concerns they would like to raise. Of those who agreed that they have their own concerns, with reasons among others: deadlines in submitting requirements; requirements needed to pass for the subject; activities that are suited to discussions; internet connection that has to be improved; and the appropriate device that students used for their online classes.

Table 7. Students' concerns during online learning $(n=1,138)$

\begin{tabular}{ccc}
\hline Opinions & n & \% \\
\hline Yes & 538 & $47.28 \%$ \\
No & 389 & $34.18 \%$ \\
I do not know & 211 & $18.54 \%$ \\
\hline
\end{tabular}

Students highlighted some online tools which could be helpful for their online learning (Table 8): Pre-recorded videos (57), Google Classroom and Meet (44), Zoom (29), and PowerPoint (27). Students also cited three most important activities which need to be enhanced in making online classes successful and enjoyable: Flexible learning (225), usage of interactive videos (135), and consideration or leniency (83). It is reported that some students are concerned in the online tools and activities they used for online classes.

Virtual platforms are intended to help students in accomplishing a certain task or activity and should be used to expand access to learning opportunities for all of them. Thus, these will help improve the students to grasp essential skills needed in the online learning. On the other hand, activities should be engaging for students who are involved in the process. They do not only encourage the learners to participate in the lessons from their professors, but at the same time, build their strength and motivation to keep up with their interests during e-learning. 
Table 8. Suggestions for improvement in the online learning

\begin{tabular}{ccc}
\hline Classification & Response & n \\
\hline \multirow{3}{*}{ Online tools } & Pre-recorded videos & 57 \\
& Google Classroom / Meet & 44 \\
& Zoom & 29 \\
Activities & PowerPoint & 27 \\
& Flexible learning & 225 \\
& Interactive videos & 135 \\
& Consideration / Leniency & 83 \\
\hline
\end{tabular}

\section{Conclusions and Recommendations}

E-learning or Online learning makes a huge transition in the educational system in light of the COVID-19 pandemic, which presented varied opportunities for all students in acquiring skills and competencies. With this method, it is also a way for the learners to be free of what they have known and what they have learned prior to the actual virtual classroom at present time. The students became aware of the resources (particularly smartphones) that can be useful at homes, including preferred platforms such as Google Classroom, Facebook Messenger, Edmodo, and Google Meet. In similar vein, the students' experiences during online were varied.

Hence, the students became familiar with the activities and tools in the online learning since they preferred more in expressing their questions in the discussion board for their concerns. Online activities should provide more interaction and communication. Majority of the students preferred activities that are self-paced. Teachers should provide enough time for students to complete any given task and perhaps, create a map for task analysis for certain group of students.

Students were also unsure if they have already developed the expected skills and competencies in e-learning.

This implies more creativity and resourcefulness in the delivery of on line instructions.

Based on the findings, it is recommended that higher education institutions should be ready in thinking creative alternative modes and in bringing new perspectives that will help and guide the students in their learning.

Moreover, teachers or curriculum developers are encouraged to redesign curriculum plan, activities, and assessment tasks to enhance attainment of learning outcome in e- learning delivery of instruction. Limitations of the study included that of the inability to conduct interview for further validation of the responses.

\section{Acknowledgments}

The authors would like to extend gratitude to St. Dominic College of Asia for the funding the research. The researchers would also like to thank Prof. Cale Jennifer Lyn Puno and Dr. Don Vicente C. Real forediting this paper.

\section{REFERENCES}

[1] E. Aboagye, J. A. Yawson, \& K. N. Appiah, (2020). "COVID-19 and e-learning: The challenges of students in tertiary institutions," Social Education Research, vol. 1, no. 1, pp. 109-115, DOI: $10.37256 /$ ser.122020422.

[2] W. Ali, (2020). "Online and remote learning in higher education institutes: A necessity in light of COVID-19 pandemic," Higher Education Studies, vol. 10, no. 3, pp. 16-25, DOI: 10.5539/hes.v10n3.

[3] E. Alqurashi, (2018). "Predicting student satisfaction and perceived learning within online learning environments," Distance Education, vol. 40, no. 1, pp. 133-148.

[4] E. T. Baloran, (2020). "Knowledge, attitudes, anxiety, and coping strategies of students during COVID -19 pandemic," Journal of Loss \& Trauma, vol. 25, no. 8, pp. 635-642, DOI: $10.1080 / 15325024.2020 .1769300$.

[5] L. Briz-Ponce, A. Pereira, L. Carvalho, J. A. Juanes-Mendez, \& F. J. Garcia-Peñalvo, (2016). "Learning with mobile technologies - Students' behavior," Computers in Human Behavior, vol. 72, pp. 612-620.

[6] H. Cigdem \& M. Ozturk, (2016). "Critical components of online learning readiness and their relationships with learner achievement," Turkish Online Journal of Distance Education, vol. 17, no. 2, pp. 98-109.

[7] R. C. Clark \& R. E. Meyer, (2016). "E-Learning: Promise and pitfalls," in E-Learning and the science of instruction: Proven guidelines for consumers and designers of multimedia learning, 4th ed., John Wiley \& Sons, pp. 1-26.

[8] J. W. Creswell \& J. D. Creswell, (2017), "The selection of a research approach," in Research design: Qualitative, quantitative, and mixed methods approaches, 5th ed., SAGE Publications, Inc., pp. 3-22.

[9] J. E. De Vera, (2020). "Guidelines for the prevention, control, and mitigation of the spread of coronavirus disease 2019 (COVID-19) in higher education institutions (HEIs)," Commission on Higher Education, https://ched.gov.ph/wp-c ontent/uploads/CHED-ADVISORY-7-final.pdf

[10] S. Harandi, (2015). "Effects of e-learning on students' motivation," Procedia - Social and Behavioral Sciences, vol. 181, pp. 423-430, DOI: 10.1016/j.sbspro.2015.04.905.

[11] B. Landrum, (2020). "Examining students' confidence to learn online, self-regulation skills and perceptions of satisfaction and usefulness of online classes," Online Learning Journal, vol. 24, no. 3, pp. 128-146, DOI: 10.24059/olj.v24i3.2066.

[12] M. V. Mahajan \& R. Kalpana, (2018). "A study of students' perception about e-learning," Indian Journal of Clinical Anatomy and Physiology, vol. 5, no. 4, pp. 501-507.

[13] F. Martin \& D. U. Bolliger, (2018). "Engagement matters: 
Student perceptions on the importance of engagement strategies in the online learning environment," Online Learning Journal, vol. 22, no. 1, pp. 205-222, DOI: 10.24059/olj.v22i1.1092.

[14] J. Miks \& J. McIlwaine, (2020). "Keeping the world's children learning through COVID-19," UNICEF, https://www.unicef.org/coronavirus/keeping-worlds-childre n-learning-through-covid-19.

[15] P. Mondal \& M. Das, (2015). “Acceptability of distance education among students' society," International Journal of Social Science and Humanities Research, vol. 3, no. 1, pp. 234-239.

[16] J. Moreillon, (2015)."Increasing interactivity in the online learning environment: Using digital tools to support students in socially constructed meaning-making," TechTrends, vol. 59 , no. 3, pp. 41-47.

[17] A. Rasouli, Z. Rahbania, \& M. Attaran, (2016). "Students' readiness for e-learning application in higher education," Malaysian Online Journal of Educational Technology, vol. 4, no. 3, pp. 51-64.

[18] E. Reyes-Chua, B. G. Sibbaluca, R. D. Miranda, G. B. Palmario, R. P. Moreno, \& J. T. Solon, (2020). "The status of the implementation of the e-learning classroom in selected higher education institutions in Region IV-A amidst the COVID-19 crisis," Journal of Critical Reviews, vol. 7, no. 11, pp. 253-258, DOI: http://dx.doi.org/10.31838/jcr.07.11. 41.

[19] L. Salamat, G. Ahmad, M. I. Bakht, \& I. L. Saifi, (2018)."Effects of e-learning on students' academic learning at university level," Asian Innovative Journal of Social Sciences \& Humanities, vol. 2, no. 2, pp. 1-12.

[20] A. Shukri, L. Nordin, F. I. Mohd Salleh, S. N. Mohd Raidzwan, \& R. Ahmad, (2020). "UniKL students' perception on synchronous learning using ICT as learning tools to learn English," Journal of Critical Reviews, vol. 7, no. 8 , pp. 793-796, DOI: 10.31838/jcr.07.08.170.

[21] C. M. Toquero, (2020). "Emergency remote education experiment amid COVID-19 pandemic in learning institutions in the Philippines," International Journal of Educational Research and Innovation, vol. 15, pp. 162-176, DOI: $10.46661 /$ ijeri.5113.

[22] A. F. Umbit \& M. S. Taat, (2016)."The effects of expectations and satisfaction towards e-learning among students," Journal of Modern Education Review, vol. 6, no. 9, pp. 603-611, DOI: 10.15341/jmer(2155-7993)/09.06.201 $6 / 004$. 